\title{
Conflict in Nursing Management in the Hospital Context ${ }^{1}$
}

\author{
Soeli Teresinha Guerra ${ }^{2}$ \\ Adelina Giacomelli Prochnow ${ }^{3}$ \\ Maria Auxiliadora Trevizan ${ }^{4}$ \\ Laura de Azevedo Guido ${ }^{5}$
}

This qualitative study aimed to analyze how conflicts manifest in interpersonal relations and the dimensions they assume in nursing management in hospitals. Data were collected through semi-structured interviews with 13 nurse managers from hospitals in the interior of Rio Grande do Sul, Brazil. Content analysis was used to interpret the results. Among the results, it was highlighted that: a) 11 of the 13 nurses have been managers for more than $80 \%$ of their time since graduation and expressed that they had no idea about the management role before taking up this function; b) the nurses consider that conflicts are immanent in the organization, entailing the need to live and interact with them; c) internal conflicts showed to be the most determining for the managers. There is a need to understand the origin of conflicts and factors favoring their establishment, as well as to acknowledge the importance of an interdisciplinary response.

Descriptors: Nursing; Conflict (Psychology); Management; Nursing, Supervisory; Hospital Administration.

\footnotetext{
${ }^{1}$ Paper extracted from Master's Thesis "O conflito no exercício gerencial do enfermeiro no contexto hospitalar", presented to Programa de Pós-Graduação em Enfermagem, Universidade Federal de Santa Maria, RS, Brazil.

${ }^{2}$ RN, M.Sc. in Nursing, Hospital Universitário de Santa Maria, RS, Brazil. E-mail: soeliguerra@uol.com.br.

${ }^{3}$ RN, Ph.D. in Nursing, Adjunct Professor, Departamento de Enfermagem, Universidade Federal de Santa Maria, RS, Brazil. E-mail: agp.sma@terra.com.br.

${ }^{4}$ RN, Ph.D. in Nursing, Full Professor, Escola de Enfermagem de Ribeirão Preto, Universidade de São Paulo, WHO Collaborating Centre for Nursing Research Development, SP, Brazil. E-mail: trevizan@eerp.usp.br.

${ }^{5}$ RN, Ph.D. in Nursing, Adjunct Professor, Departamento de Enfermagem, Universidade Federal de Santa Maria, RS, Brazil. E-mail: Iguido@terra.com.br.
}

Corresponding Author: Soeli Teresinha Guerra Hospital Universitário de Santa Maria Avenida Roraima, Prédio 22 Bairro: Camobi CEP: 97105-900 Santa Maria, RS, Brasil E-mail: soeliguerra@uol.com.br 


\title{
O conflito no exercício gerencial do enfermeiro no âmbito hospitalar
}

Este é um estudo qualitativo, cujo objetivo foi analisar como os conflitos se manifestam nas relações interpessoais e a magnitude que assumem no exercício gerencial do enfermeiro, em hospitais. Os dados foram coletados por meio de entrevista semiestruturada com 13 enfermeiras gerentes de hospitais, do interior do Rio Grande do Sul. Para a interpretação dos resultados, utilizou-se a técnica de análise de conteúdo. Entre os resultados, destacaram-se: a) 11 das 13 enfermeiras estão na função de gerente há mais de $80 \%$ do período após a graduação e expressaram que não tinham ideia sobre o papel gerencial antes de assumir a função; b) as enfermeiras compreendem que os conflitos são imanentes à organização, sendo necessário conviver e interagir com eles e c) os conflitos internos revelaram-se como os mais marcantes para as gerentes. É preciso compreender a origem dos conflitos, os fatores que favorecem sua instalação e reconhecer a importância de abordá-los interdisciplinarmente.

Descritores: Enfermagem; Conflito (Psicologia); Gerência; Supervisão de Enfermagem; Administração Hospitalar.

\section{El conflicto en el ejercicio gerencial del enfermero en el ámbito hospitalario}

\begin{abstract}
Estudio cualitativo cuyo objetivo fue analizar como los conflictos se manifiestan en las relaciones interpersonales y la magnitud que asumen en el ejercicio gerencial del enfermero en hospitales. Los datos fueron recolectados por medio de entrevista semiestructurada con 13 enfermeras gerentes de hospitales del interior del estado de Rio Grande del Sur. Para la interpretación de los resultados se utilizó la técnica de análisis de contenido. Entre los resultados, se destacó: a) 11 de las 13 enfermeras estaban en la función de gerente hace más de $80 \%$ del período de graduadas y expresaron que no tenían idea sobre el papel gerencial antes de asumir la función; b) las enfermeras comprenden que los conflictos son inmanentes a la organización, siendo necesario convivir e interactuar con ellos; c) los conflictos internos se revelaron como los más sobresalientes para las gerentes. Es preciso comprender el origen de los conflictos, los factores que favorecen su instalación y reconocer la importancia de abordarlos interdisciplinarmente.

Descriptores: Enfermería; Conflicto (Psicología); Gerencia; Supervisión de Enfermería; Administración Hospitalaria.
\end{abstract}

\section{Introduction}

Conflicts are related to the concerns that are part of humans' nature, including the defense of their goals. To reach these, they use mechanisms that permit control of the physical environment and the relations involved, even when presuming that this can result in the unexpected. The treatment given to this theme, however, is not at all as frequent as conflict occurrence. Not rarely, conflict is still treated as a villain, an unwanted presence, a situation to be avoided at any cost, even if a clear trend is observed, after the mid-20 th century, to consider it a favorable factor for institutional change $\mathrm{e}^{(1-5)}$.
In Nursing, concerns with the conflict phenomenon and the possibility of seeing it as a change factor are perceived as from the 1980's, a period when, in the organizational context, nursing activities start to move from the operational to the strategic area: one interpretation given to this phenomenon is that the characteristic elements of this universe start to be part of nurses' daily work(6).

Nursing professionals represent the majority of the workforce in hospital institutions(7). In practice, their activities range from direct patient care to activities 
that can resound in the decision-making core (indirect action), when they inform central management about all events that take place in the institutional sphere. The peculiarity grants a singular concession especially to nurses, allowing them to act with greater autonomy towards patients, in direct and indirect ways, as well as to interfere, subliminally, in decision making by central management, and makes conflict phenomena an inherent part of nurses' professional work.

In this study, conflicts are understood as "(...) the phenomena, facts, behaviors that, in organizational life, constitute 'noise' and are acknowledged as such by workers and management"(3). The conflict process comprises five stages: 1 ) latent conflict or of potential opposition or incompatibility; 2) perceived conflict or of cognition and personalization; 3) felt conflict or of intentions; 4) manifest conflict or of behavior; 5) consequences of the conflict for both. It is important for managers to clearly know these phases, so that they can try and interfere in a conflict in the stage that is considered most appropriate for the intended goals ${ }^{(5,8)}$.

In this perspective, nursing management practice is permeated by conflicts. In nurses' relation with hospital organizations, ideological elements are incorporated in the way work is organized, which remit to the idea of loyalty to organizations, of aptitude, acknowledge, of values related to the moral issue. Among the main values, the following stand out: engagement, responsibility, discipline, harmony, valuation of human beings, commitment, resulting in a feeling that demonstrates tenacity of religious and military nature, which approximates myths and symbols that serve as the base for nursing practice ${ }^{(9)}$.

Besides, nurses' management activity is often based on the principles of classical administrative theory, which centers on the productivity and rationality of work which, to a certain extent, exposes intervenient and triggering factors of conflict in power relations ${ }^{(10)}$. In this sense, a study on the expectations deriving from the management practice context, in view of the Pedagogical Project and strategies that enhance transformative nursing praxis or not, found that nurses attempt to adapt their work to co-existent care and management models, but still do not manage to achieve transformative praxis, in view of the resistance met in health service organization according to the Hegemonic Neoliberal Model, which sustains reiterating praxis $^{(11)}$.

To overcome this model, it is important to construct new management forms in nursing, which cover knowledge about health policies and their practice in the country and in hospitals, as well as the development of leadership and management competencies and skills for more interactive and dialogical practices, in which conflicts cannot be denied. Thus, management can actually represent a possibility of establishing the new in health organizations' daily reality ${ }^{(11-13)}$.

Based on the above panorama, this study was developed to analyze how conflict is manifested in interpersonal relations and its magnitude in nurses' management practice in the universe of hospital institutions.

\section{Method}

This exploratory and descriptive research used a qualitative interpretative method.

The study context comprises five hospital institutions with more than fifty beds, located in a medium-sized city in the interior of Rio Grande do Sul.

Research participants were nurses who worked or had worked as Nurse Managers or related functions for at least four years, whether continuously or not, in the last ten years, at the selected hospitals. The selection criteria for inclusion in the sample were as follows: 1) free and voluntary acceptance to participate in the group; 2) eldest occupant of the function at each institution; 3) choice of at least one nurse manager per institution; 4) progressive inclusion of professionals listed at the institution, until covering at least $50 \%$ of nurse managers from two or more services in the institution's staff. In total, 15 nurses were selected, 13 of whom granted an interview, while two interviews could not take place due to successive cancelations. The number of research participants was established based on the data saturation criterion.

Data were collected through a semistructured interview with the following guiding question: 1) Talk about what you consider relevant in your management practice; 2) Before you took up the management function, what was your idea about the nurse manager's role? Does it correspond to what you thought?; 3) How do you see yourself in situations you consider a conflict?; 4) Talk about any situation you remember about something noteworthy in management practice, involving conflict and how you dealt with it; 5) Do you plan in advance ways to address situations you consider susceptible to conflict?; and, 6) For you, does the way of dealing with conflict depend or not on the context it happens in?

All interviews were recorded with an electronic audiorecorder, full transcribed and ordered with highlights in 
different colors, producing blocks that were organized based on the focus of the approach they referred to, in order to compose the synthesis for interpretation, based on previously defined theoretical premises. Data analysis was based on the precepts of the qualitative method: ordering, classification in relevant structures, synthesis and interpretation ${ }^{(14)}$.

Approval for the project was obtained from the Ethics Committee (CAAE No 0006.0.243.000-08). Study participants received information about the research problem and signed an Informed Consent Term to formalize their agreement to participate, in compliance with National Health Council Resolution No 196/96(15). Codes were adopted to identify the subjects' testimonies, according to the order in which the interviews were held, with a view to preserving their identity.

\section{Results}

\section{Nurse managers and their practice}

The nurses who participated in the study were older than 30 years, had been graduated for between seven and 36 years and had occupied the management function for between six and 30 years. All of them continued their formal qualification after graduating, through a specialization or Master's program. Except for two, the remainder specifically qualified for the function while already working as a nurse manager. Eight out of 13 interviewed nurses were or have been a nurse manager for more than $70 \%$ of their graduation time, while one was already serving as a manager even before graduating.

When asked about what they consider relevant in management practice, the nurses primarily highlighted issues related to interpersonal relations, particularly the ability to dialogue; emotional stability, highlighting the ability to equate differences among professionals, either in the team itself or the group of other workers in the organization; and also the fight in defense of the group's expectations, which can be related to the work scale, preferences to act in a given specialty, or private issues, in the attempt to adjust family obligations and job activities.

$[\ldots]$ the range of people you work with [...] organize these differences [...] the best strategy is to talk (nurse 1). The emotional stability to deal with many types of people at work, because the person comes before the profession (nurse 6).

These statements reveal a central concern, which is to identify, clarify, elucidate the characteristics, expectations and feelings that comprise the set of subjective elements in each nurse manager's activity area. What can mutually distinguish them is the order in which these elements are arranged.

Thus, it seems due to underline the relational issue as, "if it is true that the real is relational, it can happen that I don't know anything about an institution about which I believe to know everything, because it is nothing beyond its relations with the whole"(16). The statements below are quite revealing:

The manager needs to have a great ability to understand things, he has to try and get to know the thing about the institution and the people he works with [...] ]each person is different, one job differs from the other, and people from the services are also different [...] So, we are practically a chameleon [...] a chameleon because you need to mold yourself to all of those situations, those teams, those clients who are different (nurse 8).

When analyzing nurses in management practice, among other issues, their perception about this role should be taken into account. In this research, it was evidenced that the large majority of the nurses ended up being a manager, as they were nominated beyond their will, without the slightest notion of what it meant to be one, of intervenient factors and competencies involved in this function.

For me, the management issue was very distant and, due to circumstances, you end up assuming [...] (nurse 8). It was a part like, very difficult; one because you don't have a clue [...] there are several things at that moment when we assume this kind of function, there are several charges and I really had no clue, I wasn't prepared (nurse 10).

The testimonies confirm what was said about the unknown the nurses submitted to and are submitted to inside hospital organizations. The manifest oppression blinds and denies even the possibility of questioning or asking oneself about which are and whether they have the competencies needed to do the job.

\section{Nurse managers' perception about conflict: limits and possibilities of overcoming}

For the group of interviewed nurses, overcoming is the word that best defines the intent of their struggles by considering themselves successful in this unknown and challenging undertaking called management.

We have a very small base, so I didn't know what management was... overcoming ... I wanted to conquer that obstacle (nurse 5). It was something that was conquered actually, it was never sought, you see, I started like that, not in empiricism, I had a degree, but like... I went one and saw that I was good at it (nurse 11). 
Another necessary observation when reflecting on the dilemmas of nursing is presented in a study that indicates that "it is impossible to ignore the existence of an unsteadiness that provokes tensions, demotivation and conflicts - an unsteadiness that derives from the dichotomy between theory and practice"(17). It should be reflected on what reasons actually lead to the perpetuation of that dichotomy. Could it be due to the consolidation of a habitus, in accordance with Bourdieu's theoretical construction of practices, or to knowledge reproduction in training institutions, as some nurses prefer to insist? The following statements are instigating and revealing in that sense.

I gradually learned, learned over time, doing and learning (nurse 1). I didn't know what it meant to be the head, but I learned, we learn a lot from people [...] I am a little of each good nurse at the hospital, I tried to get the best of everyone (nurse 5).

It is known that "school is a field that, more than any other, is oriented towards its own reproduction, due to the fact that, among other reasons, the agents master their own reproduction"(18). In this respect, an alert is due on the consequences changes can provoke in the relations between the social and school sphere. Now, if nurses' social image as managers can be assumed and recognized in different ways, considered real and possible, this implies saying that the academic apparatus does not only need to show itself, but also get close, interacting in and with the world where practice happens. Thus, like organizations, academic institutions need to prepare themselves for professionals' integrated insertion in the job market.

The manifestations below express the nurse managers' feeling on their education and what is actually awaiting them in hospital management.

We have never been prepared for management, schools did not prepare for management, the most you managed to do is to manage your patient, management like, of services, of different services like what we do today, there is no preparation for that (nurse 8). I didn't know anything about management, I had that administration from college, that formula need times number of people, workplace times hour load [...] which did not give us support to truly face a leading function, in human resources (nurse 11 ).

If, on the one hand, the clinical nurses who serve as managers in hospitals consider themselves, to a certain extent, aggrieved, hindered, jettisoned from access to the necessary knowledge for what they consider satisfactory in management practice, on the other, it needs to be revealed, exposed clearly and without subterfuges what reasons truly justify this privation, if it actually exists.

Regarding conflict perception, it was verified through the interviewed nurses' statements that most of them perceive the phenomenon as an incorporated and constant element in management practice. This understanding that conflicts are present in daily reality as perceived phenomena and as part of the set of intervenient factors nurses need to live and interact with in their daily work permits setting the declarations in the time period of the human relations view.

We live with conflict constantly [...] (nurse 1). There are various conflicts and they depend on the situations (nurse 5 ). The conflicts are almost daily and, when you manage many services, they are repeated a lot and are also very similar from sector to sector (nurse 8).

It was found, however, that the traditional conflict view still exists in some nurses' perception. According to this view, conflict is perceived as something bad, harmful, which should be avoided.

Conflicts, unfortunately, are always present; and the main problem really is when a conflict is established (nurse 3 ). I, during these eight years I had, you may say that I haven't had conflict problems (nurse 9 ).

In reports on distinctive experiences deriving from conflict situations, most of the nurses expressed interpersonal conflicts, involving emotive relations, or a wide range of manifestations of incompatibilities in contact among people, which are mentioned as the most difficult to manage.

I couldn't imagine that, in management, we'd have so many problems involving teams inside the hospital in affective, love issues. That's very noteworthy (nurse 4). I think that, at that time, I could feel that the staff really never liked me very much. At that time, I had a head who was much closer to the others (technicians/auxiliaries) than to the coordination, which ended up dividing this group (nurse 10). There was a problem there with $[\ldots]$. There was no solution there so the board thought it was better I'd leave and each went her own way [...] There are more conflicts with nurses I think (nurse 12).

\section{Discussion}

The interviewees' statements reveal that internal conflicts between nursing team professionals are the most distinctive for most nurse managers. There is plenty of evidence that they struggle between legalism and urgent needs, emotion and application of the rule, ethical dilemmas and survival in the function. It is perceived that the nurse managers' main movements turned into attempts to accommodate the group members in their 
respective functions, so as to avoid inciting disputes.

To better interpret the what, why and what ends encompass the events that tension relations in the hospital environment, it would be of help to keep in mind the understandable precaution of the field concept ${ }^{(19)}$. In the same way as the author appoints existing differences among different fields, it is deducted that the hospital space is like others because it is "a social universe like others, where one deals like elsewhere with capital power, relations of strength, struggles to preserve or transform these relations of strength, strategies for maintenance or subversion, interests, etc.".

It is inferred that, possibly, the nurse managers need to deepen their knowledge on the organizational universe, its intrigues, its relations with internal and external agents, what values are reflected in the institutional view and mission, in order to professionalize the function they perform.

A study on nursing care management suggests that reflecting on the social and organizational context nurses are immersed in leads these professionals to the possibility of becoming critical towards the institutional organization and the organization itself of nursing workers. Although nurses work in institutions that fragment knowledge and try to annul the notion of human, based on the interpretation of the established, they can let flourish the human aptitudes characteristic of $\operatorname{man}^{(20)}$.

The set of competencies associated with a body of knowledge comprises education, one of the aspects in the conception of an organization's work places. In this sense, if a job requires complex and non-rationalized knowledge and competencies that require workers to spend time on their learning, it is the type of job defined as a craft. But, when the knowledge and competencies necessary for the job were identified before that person starts to work, this is called professional work ${ }^{(21)}$. Based on the author's concept, a fundamental question emerges: does the management function nurses perform inside hospital organizations fit into the definition of craft or professional work?

$A$ research on the construction of management knowledge and the conformation of nursing competencies to take charge of and conduct management work in health and nursing appoints that nursing education and praxis should move among work processes in the caregiving, management, educative and scientific research dimensions. Thus, nurses can assume their role as articulators in the system, in health services and care, from the perspective of comprehensiveness, of teaching-service integration, attending to the population's demands and building routes to put the health system in practice ${ }^{(11)}$.

In view of the conflict situations that mark nurses' management practice, various questions can be raised. The fact that there are no objective answers to evident questions, and to so many others that may come about, does not mean that nurse managers should feel intimidated by pernicious situations in the service or structure under their command. In view of such circumstances, the best thing to do may be to weigh, temporarily observe the agents' movements, articulate support for planned measures, or simply be aware that questions are coherent and be prepared to avoid surprises. Sometimes, watching out for the unexpected is the best thing to do at times of little certainty.

Proposing transformations that start with demands for intervention external to the environment can minimally trigger two developments: in the first place, investment in strategically vulnerable actions to consolidate the intended change; second, commitment of the team's expectation in case mistaken actions are undertaken.

The feeling of institutionalized passiveness the nurses reflect can turn into the detonator of an action that, when triggered, entails positive effects for everyone. In certain exemplifying circumstances the interviewees described, this passiveness constituted the core element to change a questionable habitus for the nursing team. The group's neutrality permitted incursions in its behaviors, which enhanced the nurse managers' actions in favor of rupture, evidenced in the disequilibrium of strengths between agents in the field.

The change process is described as a result of the struggles between agents who, in function of their position in the field, associated with their peculiar capital, take interest in preserving, i.e. in routinizing, or in subverting, which frequently takes the form of a return to the beginning, of original pureness and naive criticism ${ }^{(19)}$.

It is considered that, even if unconsciously, the nurse managers display intentionality favorable to rupture. However, one essential inquiry continues: to what extent do nurse managers perceive the intentions contained in ascending or descending hierarchy when a conflict occurs/is evidenced?

\section{Final considerations}

The effort made in this research was aimed at analyzing nurse managers' conception of conflict, inside 
hospital organizations, the main actions undertaken to manage the phenomenon, as well as to reflect on the theme by associating it with the management of two or more services at the hospitals where they work.

Historically, reflections on themes that permeate organizational relations, like in the case of conflict, are covered in different knowledge branches with still incipient treatment. However, in this study, efforts were made to construct an approach, at the light of the theoretical intersection between three knowledge areas, with an analogue focus on relations, in general, in Administration, Sociology and Nursing in particular, and among these.

Nurse managers' difficulty to glimpse alternatives, in a complex and clogged structural conjuncture, subjection to situations at the limit of emergence, the permanent oppression they suffer, as a result of factors internal and external to the structure they feel responsible for, reveal the maintenance of the reiterating practice that was consolidated by the nursing agents in charge, even when this transcends the category's hierarchy, and who are responsible for different services inside hospital organizations. It is in small daily actions that one consolidates a health system model and nurse managers, through their actions, most of which are more reproductive than reflexive, help to strengthen the established model.

The incorporation of new habitus demands coping and availability to sensitize institutional agents, whether these are nurses or not, to direct a new look at their practice. Mature and visceral reflection on the origin of conflicts is needed, and on the factors favoring their establishment, as well as acknowledgement of the importance of an interdisciplinary approach in treating this organizational phenomenon, in order to start the fight for a reclassification of agents inside a field.

It is observed that the positive perspectives for the future of the profession are intimately associated with the search for scientific qualification, in both theoretical and practical terms, and not only due to admiration one can conquer from other categories or society in general. This feeling needs to be transformed into respect, so that one manages to complete the so-called administrative voids in the hospital organizations the nurse managers already pass through in a solitary and invisible way.

Moreover, there is a need to unveil nurse managers' activities so that the team feels it co-participates in processes, even if as a mere spectator at some times. That is the only way it can show solidarity and support the manager's actions.
One alternative that is appointed as feasible, considering the evidence produced in this study, centers on skills development to constitute service teams in view of contextual differences. Maintaining representatives of diverging interests in the teams and equanimously distributing powers contributes to balance internal forces, administer movements that can hamper or comprise management performance and encourage collective growth.

When managers know their team and its members intimately, individually, they should attempt to organize the groups so that, when they are absent, they will feel as if they were present, permanently, at any time in the figure of those agents they consider to be their own extensions, that is, in the solid relation of trust established around common goals.

Thinking about the theoretical intersection between Nursing, Administration and Sociology in terms of work relations permitted looking at the social space where they occur and considering the relevance of setting them in their context. There seems to be no doubt on the existing entanglement between the essential cores of these three knowledge areas. It is as if, in the end, the combination of different colors, mixed, attempted to conceive an increasingly harmonious tone.

The courage to address conflict as it appears in the hospital structure, in an interdisciplinary way, materialized in the principles of Administration, strongly represented by Nursing action and the attempt to unveil its imbrications in Sociology, based on Pierre Bourdieu's concepts of habitus and field was, at the limit of possible analyses and discussions, the main contribution of this study.

\section{References}

1. Chiavenato I. Gestão de Pessoas. Rio de Janeiro: Elsevier; 1999.

2. Cecílio LCO. Disputa de interesses, mecanismos de controle e conflitos: a trama do poder nas organizações de saúde. Cad Saúde Pública. 2002;36(4):587-608.

3. Cecílio LCO. É possível trabalhar o conflito como matéria-prima da gestão em saúde? Cad Saúde Pública. 2005;21(2):508-16.

4. Farias LO, Vaitsman J. Interação e conflito entre categorias profissionais em organizações hospitalares públicas. Cad Saúde Pública. 2002;18(5):1229-41.

5. Robbins S. Comportamento organizacional. $11^{\mathrm{a}}$ ed. São Paulo: Perason Prentice Hall; 2007.

6. Brito MJM, Melo MCOL, Monteiro PRR, Costa JO. 
Interfaces das mudanças hospitalares na ótica da enfermeira gerente. RAE. 2004; 44 (espec):34-47.

7. Almeida MCP, Rocha JSY. O saber em enfermagem e sua dimensão prática. São Paulo: Cortez; 1986.

8. Marquis $B$, Huston CI. Administração e liderança em enfermagem: teoria e prática. 4a.ed. Porto Alegre: Artmed; 2005.

9. Prochnow AG, Leite JL, Erdmann AL, Trevizan MA. O conflito como realidade e desafio cultural no exercício da gerência do enfermeiro. Rev Esc Enferm USP. 2007;41(4):542-50.

10. Spagnol CA, Ferraz CA. Tendências e perspectivas da administração em enfermagem: um estudo na Santa Casa de Belo Horizonte - MG. Rev. Latino-Am. Enfermagem. 2002;10(1):15-20.

11. Resck ZMR, Gomes ELR. Background and managerial practice of nurses: paths for transforming praxis. Rev. Latino-Am. Enfermagem. 2008;16(1):71-7.

12. Bernardino $E$, Felli VEA. Knowledge and power necessary to reconstruct nursing after management changes at a teaching hospital. Rev. Latino-Am. Enfermagem. 2008;16(6):1032-7.

13. García GI, Santa-Bárbara EI. Relationship between nurses' leadership styles and power bases. Rev. LatinoAm. Enfermagem. 2009;17(3):295-301.

14. Minayo MCS. O desafio do conhecimento: pesquisa qualitativa em saúde. 10 ed. São Paulo: Hucitec/Rio de Janeiro: Abrasco; 2007.

15. Ministério da Saúde (BR). Conselho Nacional de Saúde. Aspectos éticos da pesquisa envolvendo seres humanos Resolução 196 de 10 de outubro de 1996. Brasília; 1966.

16. Bourdieu P. O poder simbólico. Rio de Janeiro: Editora Bertrand Brasil; 2007.

17. Trevizan MA. Enfermagem hospitalar: administração \& burocracia. Brasília: Editora Universidade de Brasília; 1988.

18. Bourdieu P. Coisas ditas. São Paulo: Editora Brasiliense; 2004.

19. Bourdieu P. Razões práticas sobre a teoria da ação. 7 ed. São Paulo: Papirus; 2005.

20. Prochnow AG, Leite JL, Erdmann AL. Teoria interpretativa de Geertz e a gerência do cuidado: visualizando a prática social do enfermeiro. Rev. LatinoAm. Enfermagem. 2005;13(4):583-90.

21. Mintzberg H. Estrutura e dinâmica das organizações.

3. ed. Portugal: Editora Dom Quixote; 2004. 